\title{
Utilization Of Clover Plants For Economic Improvement Of Investa Dana Dollar Mandiri In Setro Village
}

\author{
Dewi Nuraini*1, Evianah ${ }^{2}$,Hendra Prasetya ${ }^{3}$ \\ ${ }^{1,2,3}$ Wijaya Kusuma University Surabaya Indonesia. \\ * Corresponding Author: \\ Email: dewinuraini@uwks.ac.id
}

\begin{abstract}
.
Community Service in Setro Village aims to provide assistance and training on the use of clover plants in this advanced pandemic era. The implementation method is carried out by providing training and assistance in the practice of making various preparations with clover raw materials such as making peanut brittle, cilok and clover nuggets. Where the participants presented are PKK cadres and village officials who are expected to be able to share their knowledge with other communities so that they can also be used for entrepreneurship in order to be able to help improve the family economy in difficult times like today.
\end{abstract}

Keywords: the benefits of clover, processed food, independent family.

\section{INTRODUCTION}

Clover is a type of water fern (Salviniales) from the Marsilea.lagi clan in Indonesia. In Indonesia, this plant is easily found in rice fields or at the edge of irrigation canals, or even in the yard of the house.As a plant that has many benefits, it would be wise for us to take advantage of what Allah has created on this earth, as a form of gratitude for His creation. Proper use can create new opportunities to be creative and innovate, as well as explore the potential of nature as a form of local wisdom. Local wisdom is formed as a cultural advantage of the local community and geographical conditions in a broad sense. Local wisdom contains high life values and deserves to be explored, developed, and preserved as a socio-cultural change and modernity. 1

Local wisdom is a view of life and knowledge as well as various life strategies in the form of activities carried out by local communities in responding to various problems in meeting their needs. In a foreign language, it is often conceptualized as a local policy of local wisdom or local knowledge "local knowledge" or local genius local intelligence. Utilizing agricultural land that is still wide and unused around the Setro area, Meganti-Gresik is planted with clover which can be used as processed products which can then be an opportunity for entrepreneurship. According to Edy Sedyawati in "local wisdom" are various patterns of actions and results of material culture. In a broad sense, it means, "local wisdom" is embodied in all cultural heritage, both tangible and intangible. 2 
Clover plants that grow wild in rice fields and are now cultivated are reasons to use them into processed products that are useful for creating new businesses, for example being used as clover peanut brittle, clove filled clover, and clover nuggets. In Setro Village, its natural potential has not been utilized properly. The residents also enjoy entrepreneurship, there are also mothers who are active by opening a Setro rengginang business where in 2014 they also had the opportunity to do community service for marketing and innovation of rengginang products. The condition of the ongoing COVID-19 pandemic has made many people try how to continue living even in difficult conditions. The service in Setro Village is carried out with the aim of providing training and assistance in the manufacture of processed clover in order to improve the economy of independent families.

\section{METHODS}

Community service activities in Setro Village were carried out by a team of lecturers consisting of Dewi Nuraini, Evianah and Hendra Prasetya and there were students who helped during the training. As for the implementation, it is carried out by complying with the health protocol that has been set so that the subject of service is aimed at PKK cadres and movers who are expected to be able to communicate with members of the Setro Village community for what was conveyed when the event took place on Wednesday 2021 at 09.00 until finished.

Attended by 20 cadres and PKK movers.To avoid crowds, the Village Head gave directions to limit the time and distance during the event. So that at the time of implementation we have prepared videos and processed food products from clover that have been tried from home. So that the cadres just do a question and answer from the practice video that has been shown, In its implementation, the cadres were enthusiastic about conducting Q\&A interactions about the ingredients and methods of making clover leaf preparations in the form of clover filled clover, clover nuggets, and clover peanut brittle.

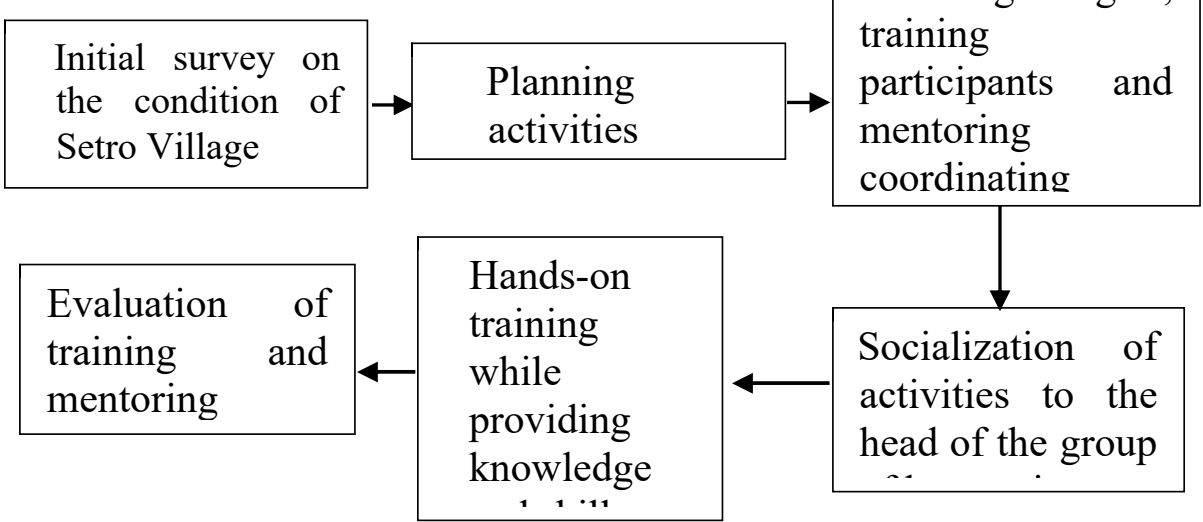

Fig 1. The implementation stage of PENMAS 


\section{International Journal Of Community Service}

In its implementation, the cadres were enthusiastic about conducting Q\&A interactions about the ingredients and methods of making clover leaf preparations in the form of clover filled clover, clover nuggets, and clover peanut brittle.

\section{RESULT AND DISCUSSION}

Community service activities were carried out on June 23, 2021, which took place at the Setro Village Hall which was attended by 20 people and accompanied by students. Where training and assistance is carried out in conditions of the COVID-19 pandemic so that you still follow the rules for using masks, keeping your distance, washing your hands/disinfecting, time is limited so that the implementation has prepared all the materials and made a video and then presented it.

Questions and answers about the technique of making processed foods from clover, related to how clover is processed. There is a question related to how to process peanut brittle so that it is crispy, this is done by using more hazelnut seasoning. Then someone else asked about the cilok how to make it chewy just right, this is done by cooking it over low heat. Then related to nuggets, there are also those who ask whether the clover is used dry or wet, can use the green one because it is fresher.
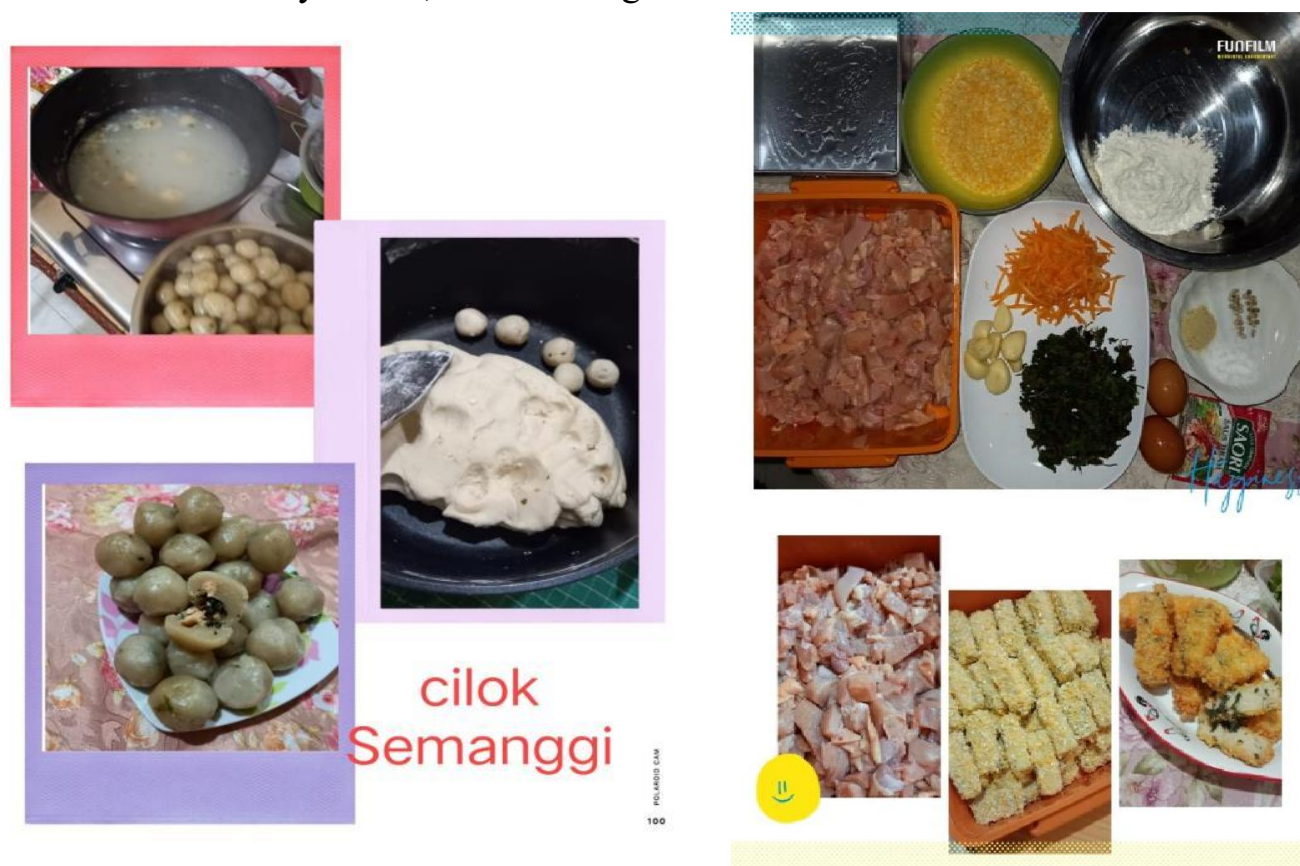


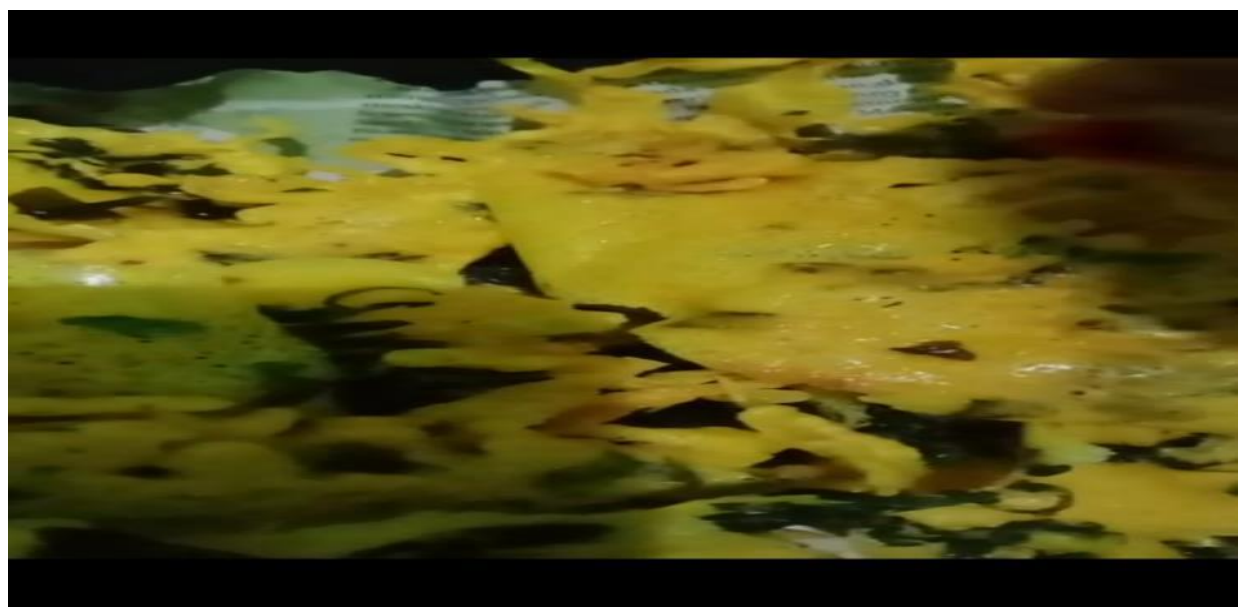

Fig 2. Processed clover

The processed clover that was distributed was how to make cilok, nuggets and peanut brittle, with the hope that PKK cadres were able to apply it as an alternative food that could be sold, in addition to using abandoned rice fields. So as to be able to open new innovative business opportunities to become economically independent families and be able to rise during the COVID-19 pandemic conditions which made many people experience the impact.
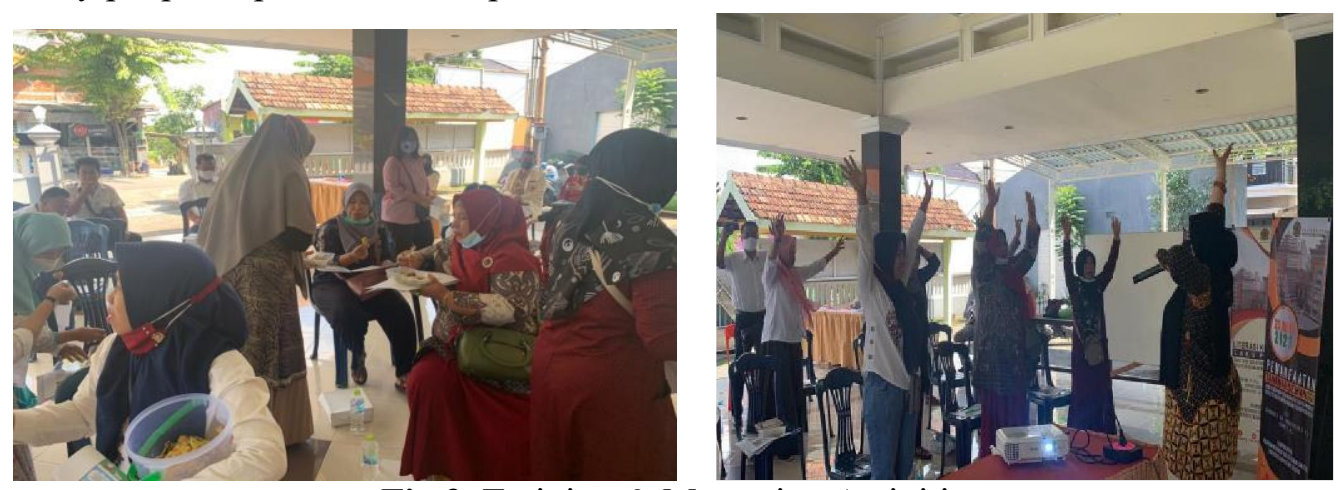

Fig 3. Training \& Mentoring Activities

Figure 3 shows the training and mentoring activities that took place with the enthusiasm of participants participating in the service activities, starting with the concentration of body movements in dealing with the pandemic. And enthusiastic participants in the activity because the implementation is conditioned as comfortable as possible.

\section{CONCLUSION}

Community service activities carried out in Setro Village at the time of largescale restrictions were carried out due to covid 19, one of which was to fulfill the Tridharma of Higher Education and also to motivate participants in particular to stay enthusiastic in living life during covid 19. 
Utilizing land that is not used for cultivating clover to be processed into various processed foods that can increase the selling value of the clover leaves, there are many things that can be done to become entrepreneurs,

\section{ACKNOWLEDGMENTS}

The related parties who have given permission in the implementation of this community service are:

1. The Head of Setro Village and his staff for the time and place provided for the UWKS FEB Lecturer team to do community service.

2. LPPM Wijaya Kusuma University Surabaya which provides the opportunity to be able to carry out the Tri Dharma of Higher Education.

3. The Faculty of Economics and Business UWKS which gives the permit to carry out the duties of the Tri Dharma of Higher Education.

4. The community in Setro Village, Menganti-Gresik, especially the training and mentoring participants who are willing to attend to take part in community service activities at the Setro Village Hall on Wednesday, June 23, 2021.

5. FEB UWKS students who help carry out community service activities.

6. Fellow lecturers who support each other's social services activities.

\section{REFERENCES}

[1] http://seputarpengertian.blogspot.com/2018/10/pengertian-kearifan-lokal-danbentuknya.html

[2] https://cookpad.com/id/cari/cilok

[3] https://food.detik.com/ayam/d-5088165/resep-nugget-ayam-wortel-buat-bekal-dan-laukanak

[4] https://www.kompas.com/food/read/2020/08/27/111200175/cara-bikin-peyek-kacangrenyah-dan-gurih 